\title{
KUN KAIKKI PYSYVÄINEN HAIHTUU ILMAAN
}

\author{
Marx, Karl \& Engels, \\ Friedrich, Kommunisti- \\ nen manifesti. \\ Suomentaneet Juha \\ Koivisto, Markku Mäki \\ ja Timo Uusitupa. Jy- \\ väskylä, Vastapaino, \\ 1998.
}

Äskettäin suomennetussa kirjassaan "Mediakulttuuri" (Vastapaino, 1998) Doug Kellner kertoo suosikkimääritelmänsä postmodernista yhteiskunnasta löytyvän Marxin ja Engelsin Kommunistisesta manifestista, siis kauan ennen puolivillaisten postmoderni yhteiskunta -jaaritusten: "Jatkuvat mullistukset tuotannossa, kaikkien yhteiskunnallisten olojen alituinen järkkyminen, ikuinen epävarmuus ja liike erottavat porvariston aikakauden kaikista muista. Kaikki tiukkaan piintyneet suhteet ja niihin liittyvät vanhastaan arvossa pidetyt käsitykset ja näkemykset hajoavat, kaikki vasta muodostuneet vanhenevat ehtimättä luutua. Kaikki säätyperäinen ja pysyväinen haihtuu utuna ilmaan, kaikki pyhä häväistään, ja ihmisten on lopulta pakko katsoa elämäntilannettaan ja keskinäisiä suhteitaan ilman harhakuvia." Kommunistisen manifestin julkaisemisesta tuli viime vuonna (1998) kuluneeksi 150 vuotta. Kirjoitusta juhlistettiin maailmalla teoksen uusin pai- noksin, uusin käännöksin, joukkotiedotusvälineissä ja yhteiskuntatieteellisen alan arvostetuissa aikakausjulkaisuissa. Tähän juhlintaan ja muistamiseen perustuu myös uuden suomennoksen julkaiseminen. Uuden suomennoksen esipuheessa suosiotaan Suomessakin kasvattava historioitsija Eric Hobsbawm arvioi Kommunistisen manifestin olevan mitä todennäköisimmin vaikutusvaltaisin yksittäinen poliittinen kirjoitus, joka on kirjoitettu Ranskan vallankumouksen Ihmisoikeuksien julistuksen jälkeen.

\section{Tekstissä ei säästellä} sanoja. Siinä otetaan kantaa yhteiskunnallisiin vääryyksiin sellaisilla sanoituksilla, että Kerkko Koskisellakin olisi paljon opittavaa, mikäli vielä kiinnostaisi. Yksityisomistuksesta (mutta eiks se olekaan mulle tarkoitettu juttu?): Te kauhistelette sitä, että me tahdomme lakkauttaa yksityisomistuksen. Mutta teidän nykyisessä yhteiskunnassanne on sen jäsenten yhdeksältä kymmenesosalta yksityisomaisuus poistettu.) Työ (tuttu sana): Porvarillisessa yhteiskunnassa elävä työ on vain keino lisätä kasaantunutta työtä. Kommunistisessa yhteiskunnassa on kasaantunut työ vain keino työläisten elämän avartamiseksi, rikastuttamiseksi ja edistämiseksi. Sivistys (pelkkää porvarin hapatustako?): Sivistys, jonka menettämistä porvari valittaa, on tavattoman suurelle enemmistölle sivistymistä koneeksi. Perhe (tässä vaiheessa tulee sitten jo kansalaisen pahastua): "Mihin perustuu nykyinen porvarillinen perhe? Pääomaan, yksityiseen omistamiseen. Täysin kehittyneenä se on olemassa vain porvaristolle, mutta sillä on täydennyksenään proletariaatin pakollinen perheettömyys ja julkinen prostituutio." Isänmaa (mutta hei, eihän se näin mennyt): "Kommunisteja on edelleen moitittu siitä, että he tahtovat lakkauttaa isänmaan ja kansallisuuden. Työläisillä ei ole isänmaata. Heiltä ei voida ottaa sitä, mitä heillä ei ole." (Vaan näinhän siinä kävi.) "Kansallinen eristyneisyys ja kansalliset vastakohtaisuudet häviävät yhä laajemmin jo porvariston kehittyessä, kauppavapauden, maailmanmarkkinoiden sekä teollisen tuotannon ja sitä vastaavien elinehtojen yhdenmukaisuuden myötä.“ Kaikkien maiden , verkostoitukaa!

\section{Aikuiskasvatuksen historiaan ja elävään teoriaan Marxin ja Engelsin klassikko- tekstin liittää ainakin kaksi seikkaa. Ensinnäkin maamme aikuiskasvatuksen yksi tärkeä juuri on työväenliikkeen or- ganisoima sivistystyö, työväen omaehtoinen sivistystyö. Tä- män ohjelman taustalta löytyy marxilaisia aatteita (luonnolli-}


sesti monilla eriskummallisillakin tavoilla tulkittuina). Toinen tunnettu liittymäkohta on Urpo Harvan ajattelu. Harvaahan pidetään yleisesti loistavana Marx-tuntijana, jonka säkenöivyys perustui analyysin puhtaaseen, kriittiseen tendenssiin. Asia käy selkeästi ilmi taannoisesta Harvan elämäntyötä kartoittaneesta kokoelmasta "Urpo Harva - filosofi, kasvattaja, keskustelija (Taju, 1997), jonka Reijo Wilenius arvio tässä lehdessä (1/98). Tuossa kirjassa Heikki Mäki-Kulmalan aikalaistodistus kertoo ilmastosta, jossa Harva Marxistaan kirjoitti: "Suomalaisessa tutki- mus- ja keskusteluperinteessä olivat kommunistit, sosiaalidemokraatit kuten myös ns. porvaritkin liikuttavan yksimielisiä siitä, että Marx oli tiedemies, joka oli esittänyt joukon hypoteeseja, jotka rautaisella välttämättömyydellä ohjaavat historian ja ihmisen kulkua. Vasemmistolaisten mielestä nuo hypoteesit olivat tosia (oikeistolaisten mielestä taas epätosia). Oltiin niin myötä- tai vastasukaan, ettei sukimisen ja Marxin väliin mahtunut yhtä analyyttista tulkintaa."

Onneksi jo mahtuu.

Kommunistinen manifesti on kannattavaa luettavaa, se lisää lukijansa sivistyksellistä pääomaa. Aikana, jolloin pommit repivät Jugoslaviaa muistuttaen Balkanin kirouksesta Euroopan yllä, kun kaikki pysyväinen näyttää haihtuvan utuna ilmaan, kaikki pyhä joutuvan häväistykseen, meidän olisi Marxin mukaan uskallettava katsoa valistuksen hengessä elämäntilannettamme ja keskinäisiä suhteitamme ilman harhakuvia, jos vain harhailevina ja epävalmiina kykenisimme siihen.

Juha Suoranta 